\title{
Література:
}

1. Можайкіна О.С. Актуальні питання визначення та ознак медіації. International research and practice conference "Urgent problems of law on the modern stage of statehood developmenm» (October 20-21, 2017, Lublin, Republic of Poland). Lublin, Republic of Poland, 2017. C. 78-80.

2. Єфіменко М.Ю. Роль адвоката у процесі медіації. Науковий вісник Міжнародного гуманітарного університету. Сер.: Юриспрудениія. 2015. № 13. T. 2. С. 25-27.

3. Правила адвокатської етики, затверджені звітно-вибрним з'їздом адвокатів України 2017 р. від 09.06.2017 р. )зі змінами затвердженими 3’їздом адвокатів України 15.02.2019р.). URL: https://unba.org.ua/ assets/uploads/legislation/pravila/2019-03-15-pravila-

2019_5cb72d3191e0e.pdf (дата звернення: 25.03.2021 p.).

4. Слива Л.В. Роль адвоката у вирішенні спорів, що виникають 3 адміністративних правовідносин у процесі медіації. Науковий вісник Херсонського державного університету. Серія: Юридичні науки. 2018. Вип.4. Т.2. С.121-126.

DOI https://doi.org/10.30525/978-9934-26-074-2-19

\section{ПИТАННЯ ПРАВОВОГО РЕГУЛЮВАННЯ РОЗВИТКУ ШТУЧНОГО ІНТЕЛЕКТУ В УКРАЇНI}

\author{
Стрельник В. В. \\ кандидат юридичних наук, дочент, \\ дочент кафедри приватного та публічного права \\ Сумського національного аграрного університету \\ м. Суми, Украӥна \\ Чурилова Т. М. \\ кандидат юридичих наук, дочент, \\ дочент кафедри міжнародного, європейського права \\ та циивільно-правових дисциплін \\ Сумського державного університету \\ м. Суми, Украӥна
}

В умовах настання нової епохи розвитку людства, де роботи, боти, андроїди й інші прояви штучного інтелекту, стають каталізатором індустріальної революції, можливості, створені досягненням в цій галузі, формують виклики про ризики, що породжують їх застосування для суспільства. Перед національним законодавцем постало завдання 
реагування на потреби сьогодення - втілення нововведень технічного прогресу в правові норми. Нагальною вимогою $є$ врахування юридичних та етичних наслідків у процесі нормотворення [1].

Впровадження технологій штучного інтелекту є невід'ємною складовою розвитку соціально-економічної, науково-технічної, оборонної, правової сферах. Відсутність концептуальних засад державної політики України в галузі штучного інтелекту не дозволяє створювати та розвивати конкурентоспроможне середовище. Першочерговими проблемами, що потребують невідкладного вирішення визнано: (1) низький рівень цифрової грамотності, поінформованості населення щодо загальних аспектів, можливостей, ризиків і безпеки використання штучного інтелекту; (2) відсутність або недосконалість правового регулювання штучного інтелекту (в тому числі у сферах освіти, економіки, публічного управління, кібербезпеки, оборони), а також недосконалість законодавства про захист персональних даних; (3) недостатній рівень інформаційної безпеки та захисту даних в інформаційно-телекомунікаційних системах державних органів внаслідок застарілості автоматичних систем виявлення та оцінки інформаційних загроз, невикористання потенціалу прогнозування та передбачення загроз з метою своєчасної підготовки системи до можливої атаки; (4) недосконалість механізмів прийняття управлінських рішень у публічній сфері, забюрократизованість системи надання адміністративних послуг, обмеженість доступу до інформації та iii низька якість, недостатній рівень впровадження електронного документообігу між державними органами, а також низький ступінь оцифрованості даних, що перебувають у власності державних органів складність перевірки відповідності роботи систем штучного інтелекту законодавству та існуючим етичним принципам; (5) відсутність єдиних підходів, що застосовуються при визначенні критеріїв етичності під час розроблення та використання технологій штучного інтелекту для різних галузей, видів діяльності та сфер національної економіки [2].

Згідно 3 всеукраїнським опитуванням, проведеним Інститутом Горшеніна спільно 3 групою компаній Everest у рамках дослідження «Штучний інтелект: український вимір», українці позитивно ставляться до перспектив розвитку технологій штучного інтелекту. Зокрема, $43 \%$ опитаних вважають, що, 3 огляду на всі потенційні можливості та ризики, пов'язані з розвитком «інтелектуальних машин», людство повинно продовжувати розробки у сфері штучного інтелекту, враховуючи ймовірні негативні наслідки та протидіючи їм. Третина респондентів (34\%) наполягають, що використовувати можна тільки штучний інтелект, безпеку якого доведено. Разом 3 тим кожен восьмий $(13 \%)$ готовий ризикнути, продовжуючи розробки у галузі 
штучного інтелекту незалежно від можливих загроз. 3\% вважають, що необхідно вже зараз повністю припинити всі розробки у сфері штучного інтелекту [3].

Найпоширенішою відповіддю про негативні наслідки розвитку штучного інтелекту є острахи через можливе зниження фізичної та соціальної активності людей на тлі розвитку технологій. Таку позицію висловили $53 \%$ опитаних. Близько третини респондентів (36\%) допускають, що розвиток технологій призведе до концентрації влади над людством у руках власника штучного інтелекту, $22 \%$ - до встановлення диктатури штучного інтелекту. Можливість гіршого сценарію - знищення людської цивілізації штучним інтелектом - розглядає кожен шостий українець $(16,7 \%)$. Майже $16 \%$ прогнозують збільшення кількості та масштабів техногенних катастроф. Таким чином, українці не схильні довіряти апокаліптичним сценаріям у контексті розвитку штучного інтелекту [3].

Враховуючи курс нашої держави на євроінтеграцію очевидно, що саме стандарти СС у сфері прав про робототехніку визначатимуть основи відповідних норм національного законодавства в майбутньому [4, с.52]. Переконані, що людство має пройти шлях від розгляду штучного інтелекту як об'єкта відносин до визнання за ним прав та обов'язків.

Таким чином, штучний інтелект має сприйматися виключно як можлива допомога у забезпечення життєдіяльності суспільства. Відносини у сфері прав «інтелектуальних машин» мають перебувати під постійним контролем, враховуючи їх розробку, експлуатацію, що виключає визнання штучного інтелекту суб'єктом правовідносин. Служіння людству, безпечність, відсутність будь-якої дискримінації має бути визначено та закріплено як основне завдання штучного інтелекту. Можливість контролювати «інтелектуальні машини» потребує від усього міжнародного співтовариства створення дієвої уніфікованої системи правового регулювання. Правової конкретизації потребують процес ідентифікації штучного інтелекту.

\section{Література:}

1. Курбонов А. Штучний інтелект і право. 2020. URL: https://www.businesslaw.org.ua/artificial-intelligence-and-law-4/ (дата звернення: 09.04.2020).

2. Про схвалення Концепції розвитку штучного інтелекту в Україні: розпорядження Кабінету Міністрів України від 2 грудня 2020 p. № 1556-2020-p. URL: https://zakon.rada.gov.ua/laws/show/1556-2020\%D1\%80\#Техt (дата звернення: 09.04.2021). 
3. Чубатюк Ю. Протистояти загрозам штучного інтелекту можна, не перешкоджаючи інноваціям, - експерт. URL: https://b.ua/tech/2019/01/ 15/417108_protivostoyat_ugrozam.html (дата звернення: 09.04.2021).

4. Стрельник В. В., Демченко А. М., Мироненко А. О. Правове поєднання права інтелектуальної власності та технології штучного інтелекту. Приватне та публічне право. № 4. 2020. C. 50-53. URL: http://pp-law.in.ua/archive/4_2020/12.pdf (дата звернення: 09.04.2021).

DOI https://doi.org/10.30525/978-9934-26-074-2-20

\title{
ТВОРЧІСТЬ ЯК ЕЛЕМЕНТ АВТОРСЬКОГО ПРАВА
}

\author{
Улітіна О. В. \\ кандидат юридичних наук, \\ вчений секретар \\ Науково-дослідного інституту інтелектуальної власності \\ Національної академії правових наук України \\ м. Київ, Украӥна
}

Творчість $є$ одним 3 найважливіших аспектів життя людини. Творчість можна відшукати в будь-якій діяльності, іiі наявність часто $\epsilon$ обов'язковою для існування тієї чи іншої сфери діяльності людини.

Право на свободу творчості відноситься до особистих немайнових прав, які забезпечують соціальне буття особи. Воно закріплене в ст. 309 Цивільного кодексу України, яка гарантує право будь-якої фізичної особи на свободу літературної, художньої, наукової і технічної творчості, а також на повну свободу вибору сфери, змісту та форми творчості [1]. Тобто відповідно до Цивільного кодексу України для творчості важливою ознакою є можливість вільно обирати в іїі рамках, в тому числі це стосується і способів вираження творчості, методів та прийомів, що використовуються. Право на свободу творчості - це по суті право, яке гарантує можливість самого творчого процесу, або інакше кажучи, творчої діяльності.

Проте в цивільному праві також існує право на результати такої діяльності, оскільки процес і його результат мають в юридичній площині дещо різне значення. Право на результати такої діяльності - це право інтелектуальної власності, про що вказує ст. 418 Цивільного кодексу України. Ця стаття встановлю право особи на результат не лише творчої діяльності, але й інтелектуальної [1]. 